\title{
Heliconia Cut Flower Production - a 2 year study in Hawaii
}

\author{
RICHARD A. CRILEY(1)
}

\begin{abstract}
Plants of 20 commercial heliconia cultivars or species were established at the Waimanalo Research Farm (Oahu) of the University of Hawaii as part of a research study on growth and flower production. Productivity and periodicity results from the 18 heliconia species and cultivars that survived are reported. Five plants in 7.61 pots of each genotypes were planted at spacings of $2.5 \mathrm{~m}$ in row, with between row spacings of $3 \mathrm{~m}$ in July 1999. Beginning a month later, newly emerged shoots were tagged every four weeks. At flowering, the shoots were harvested and leaf counts made. The information derived from the data include time frame from shoot emergence to flower, shoot production during the first year, percentage of shoots from each tag date that flowered and the periodicity of flowering during a two year period following planting.
\end{abstract}

Keywords Heliconiaceae, seasonal flowering, tropical floriculture.

\section{RESUMO}

As plantas de 20 cultivares ou espécies comerciais do helicônia foram plantadas na Fazenda Experimental de Waimanalo (Oahu) da Universidade de Havaí como parte de um estudo da pesquisa no crescimento e na produção da flor. Neste trabalho são relatados os resultados da produtividade e da periodicidade de 18 espécies e cultivares de helicônia. em julho 1999, cinco plantas de cada genótipo foram plantadas em vasos de 7,6 litros dispostos em afastamentos de 2,5 m na fileira e $3 \mathrm{~m}$ entre fileiras. Um mês mais tarde, as brotações foram etiquetadas e observadas a cada

Palavras-chave: Heliconiaceae, florescimento sazonal, floricultura tropical.

\section{INTRODUCTION}

Heliconia flowering is seasonal for many species, leading to oversupply in some periods and few or no flowers for other times of the year. Growers would benefit by knowing when flowers can be expected and how many (CRILEY 2000, 2005). Results for some cultivars have been previously published (CRILEY et al., 2001, 2003; CRILEY and MACIEL, 2005; CRILEY and UCHIDA, 2004, 2005; MACIEL and CRILEY, 2000).

The specific objectives of this study were to determine the rate of shoot and flower production, the time from shoot emergence to harvest of the inflorescence, and the effect of season on growth and development characteristics.

\section{MATERIALS AND METHODS}

The site of the research was the Waimanalo Research Farm (Oahu) of the University of Hawaii located $25 \mathrm{~m}$ above sea level. The daily photoperiod varies between $10 \mathrm{~h} 30 \mathrm{~min}$ and $13 \mathrm{~h} 26 \mathrm{~min}$ (+ $20 \mathrm{~min}$ until twilight), the average daily light integral ranges from 22 to $47 \mathrm{M} \cdot \mathrm{m}^{-2}$.day${ }^{1}$, and the monthly average temperatures range between 20 and $26^{\circ} \mathrm{C}$. Normal yearly rainfall is about $800 \mathrm{~mm}$.
Five plants of each species and cultivar (table 1) in 7.61 pots were transplanted into a prepared field on 1 July 1999. The between-row spacing was $3 \mathrm{~m}$ and the in-row spacings were $2.5 \mathrm{~m}$. A drip-emitter irrigation system was installed initially that provided $361 \mathrm{water} / \mathrm{hr} / \mathrm{plant}$, and irrigation was provided twice a week for 3 hours each time; the system was changed to a spray stake $(241 / \mathrm{hr}$ twice a week for 3 hours each time) after 10 months as the clump diameters had increased beyond the range of the drip emitters. Beginning a month after transplanting, shoots that had emerged in the previous month were identified with color-coded tags representing the month of shoot emergence (SE). While every effort was made to tag every shoot, inevitably, some were missed; thus the percent of flowering shoots harvested exceeded 100 for some months. At flowering (harvest $=\mathrm{H}$ ) the shoots were cut at ground level and leaf counts were made. Thefts from the field decreased the recordable yields.

From the data we derived information on the rate of flower and shoot production, percentage of shoots from each tagging date that flowered and the time from shoot emergence to harvest (SEàH). Data-recording operations were performed at 28-30 day intervals in the first year and at 2 week intervals in the second; thus days to harvest from shoot emergence are not more precise than \pm 14 days, as well, since the shoot emergence days varied over a 30 day period.

${ }^{(1)}$ Department of Tropical Plant and Soil Sciences, University of Hawaii, Honolulu, HI 96822. E-mail: Criley@ hawaii.edu 


\section{RESULTS}

Over 7000 marketable cut flower stems were harvested during the 2 years following planting. Some heliconias were extremely productive while others were slower-growing and produced fewer stems (table 1). Of the original 20 varieties, six did not establish well: three color forms of $H$. angusta, $H$. orthotricha 'Candy Cane', $H$. caribaea 'Purpurea', and $H$. chartacea. Replacement plants of $H$. caribaea 'Purpurea' were installed, and data were collected from the few plants of $H$. chartacea and $H$. orthotricha 'Candy Cane' that survived.

The most productive heliconias, in terms of new shoot production and ultimate flower yields were the interspecific hybrids (presumed hybrids between $H$. psittacorum and $H$. spathocircinata): 'Keanae', 'Yellow Parrot' (also known as 'New Yellow Torch'), and 'Guadaloupe' [also known as 'Guyana' (GUTTMAN, 2003)]. Among the large-flowered types, the $H$. bihai selections were vigorous and high-yielding: 'Peachy Orange', 'Claw \#2', and 'Incredible Orange', and $H$. $\times$ rauliniana. Intermediate in shoot production, but ultimately with good yields were $H$. dmitri 'Hot Rio Nights', $H$. rostrata '10 Day Rostrata', and $H$. stricta 'Red Stricta'. Of the $H$. orthotricha selections, 'Eden Pink', 'Garden of Eden', and 'Macas Pink' were superior to 'Candy Cane'. The interspecific hybrid 'Temptress' (thought to be $H$. platystachys x $H$. chartacea) was not a heavy producer. H. caribaea 'Purpurea' also did not produce many inflorescences, but nearly every shoot ultimately did flower.

Seasonal flowering was observed for $H$. bihai 'Incredible Orange', 'Claw \#2', and 'Peachy Orange', $H$. stricta 'Red stricta', $H$. dmitri 'Hot Rio Nights', $H . \times$ rauliniana, $H$. angusta 'Yellow Christmas', and $H$. rostrata 'Ten Day Rostrata'. Year around flowering was very good for interspecific hybrids 'New Yellow Parrot', 'Keanae', and 'Guadaloupe'. Intermittent year around flowering occurred in the $H$. orthotricha cultivars, while low, but continuous production was observed for $H$. caribaea 'Purpurea' and the 'Temptress' hybrid. In this study, H. chartacea 'Sexy Pink' produced a few flowers year-round, unlike a previous study (CRILEY and LEKAWATANA, 1995) in which production was low to non-existent in the spring months. H. angusta is known to be seasonal (SAKAI et al., 1990) with initiation occurring under long days and flowering (in Hawaii) in the short days of winter.

The most rapid flowering from shoot emergence occurred for the cultivars 'New Yellow Parrot' and 'Keanae' (4 to 5 months) while 'Temptress' (310 to 391 days), $H$. caribaea 'Purpurea' (261 to 355 days), and 'Incredible Orange' in its second year (360 days) required the longest time to develop inflorescences. Heliconias are very light dependent in their flowering, responding to the daily light integral (STILES, 1979), and some are photoperiod-sensitive as well (CRILEY et al., 1999). The $H$. angusta materials, however, would probably have done better in a partially shaded environment.

\section{ACKNOWLEDGEMENT}

This research was undertaken as a part of a larger project funded by a USDA Special Grants Program for Tropical and Subtropical Agriculture (T-STAR agreement 98-
34135-6783) to evaluate heliconia species for their adaptability, productivity, and suitability as cut flowers.

\section{LITERATURE CITED}

CRILEY, R.A. Seasonal flowering patterns for heliconia shown by grower records. Acta Horticulture. v.541, p. 159-165, 2000.

CRILEY, R.A. Heliconia productivity study 1999-2001. pp 31-35. Proc. 2004 Hawaii Floriculture Conference. Leonhardt, K. W. and P. Nakao (Eds.), Coll. Trop. Agric. Human Resources, Univ. Hawaii. CTAHR Proc. P-04/05, 2005.

CRILEY, R.A.; LEKAWATANA, S. Seasonality of flowering in Heliconia chartacea and the potential for its control. Heliconia Society International Bulletin. FL. Lauderdale, v.7, n.4, p.11-15, 1995.

CRILEY, R.A.; MACIEL, N. Seasonal production among some tropical cut flowers. pp 36-44. Proc. 2004 Hawaii Floriculture Conference. Leonhardt, K. W. and P. Nakao (Eds.), Coll. Trop. Agric. Human Resources, Univ. Hawaii. CTAHR Proc. P-04/05, 2005.

CRILEY, R.A.; Maciel, N.; FU,Z.; UCHIDA, J. Productivity of three Heliconia hybrids. Heliconia Society International Bulletin. FL. Lauderdale, v.10, n.3, p.1-3, 2001.

CRILEY, R.A.; SAKAI, W.S. LEKAWATANA, S.; KWON, E. Photoperiodism in the genus Heliconia and its effect upon seasonal flowering. Acta Horticulture. v.486, p.323-327, 1999.

CRILEY, R.A., UCHIDA, J.Y.; FU, Z. Productivity and periodicity of flowering in Heliconia orthotricha cultivars. Acta Horticulture. v.624, p.207-212, 2003.

CRILEY, R.; UCHIDA, J. Hot Rio Nights in Hawaii. Heliconia Society International Bulletin. FL. Lauderdale, v.11, n.1, p.9-11, 2004.

CRILEY, R.A; UCHIDA, J.Y. That twisted Heliconia X rauliniana Heliconia Society International Bulletin. FL. Lauderdale, v.12, n.2, p.10-12, 2005.

GUTTMAN,E. Heliconias de Zingiberales Garden. Zingiberales Garden Publications, Rio Grande, Puerto Rico, 2003.

MACIEL, N.; CRILEY, R.A.. Effects of natural and simulated short-day on the flowering of Heliconia rostrata Ruiz and Pavon. Heliconia Society International Bulletin. FL. Lauderdale, v.10, n.1-2, p.12-16, 2000.

SAKAI, W.S.; MANARANGI, A.; SHORT, R.; NIELSON, G; CROWELL, M.D. Evidence for long-day flower initiation in Heliconia angusta cv. Holiday - Relationship between time of shoot emergence and flowering. Heliconia Society International Bulletin. FL. Lauderdale, v.4, n.4, p.1-3, 1990.

STILES, F.G. Notes on some natural history of Heliconia (Musaceae) in Costa Rica. Brenesia. v. 15 (Suppl.), p.151180, 1979. 


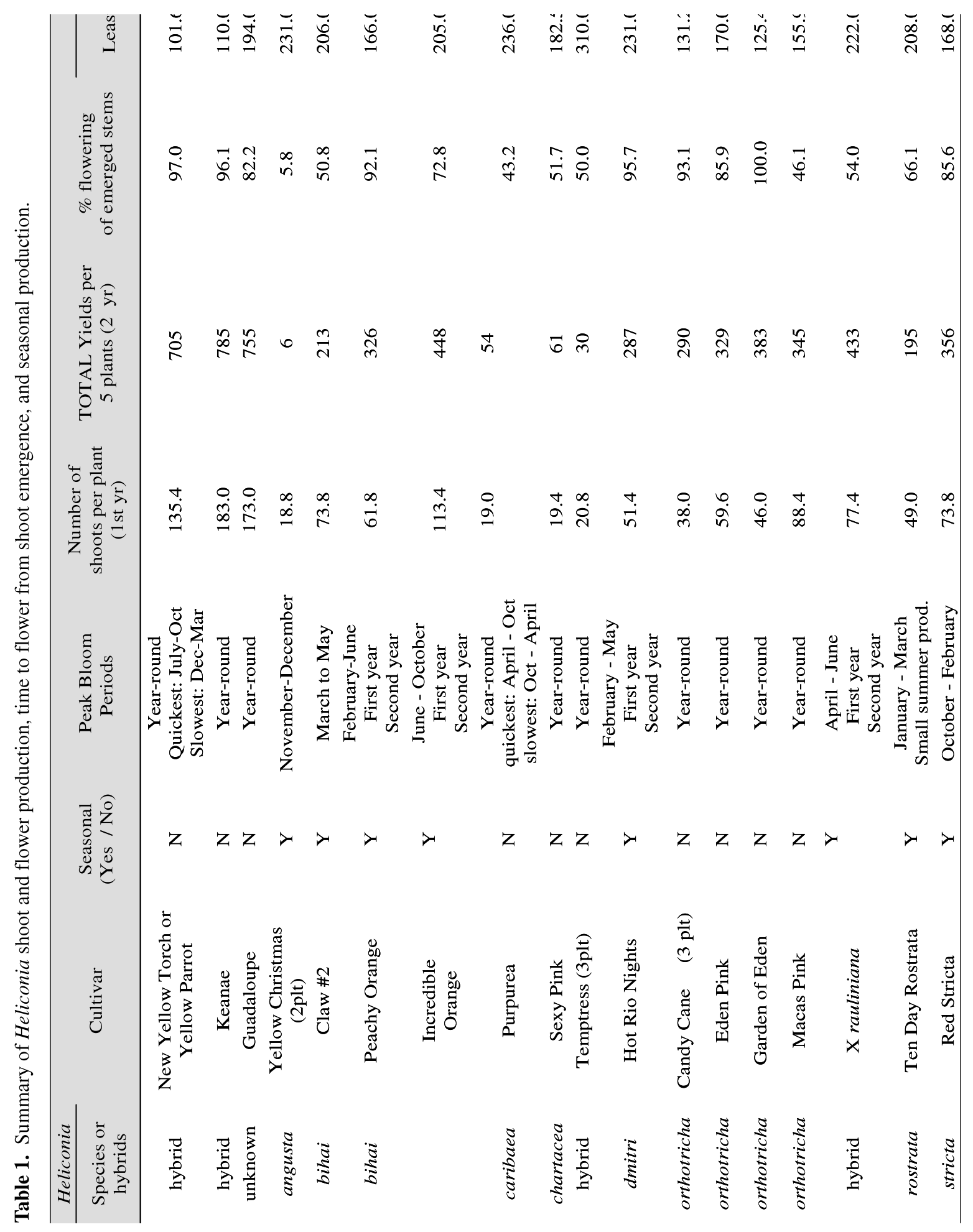




\section{H. orthotricha 'Macas Pink'}

- Seasonality: Year-round

- Total yield (18 months) for five plants: 345

- Percent of emerged shoots that flowered: 46.1

- Days from Shoot Emergence to Harvest

Shortest time to bloom: 156

Mean time to bloom: 180.8

Longest time to bloom: 322

\section{H. orthotricha 'Candy Cane'}

- Seasonality: Year-round

- Total yield (18 months) for 3 plants: 290

- Percent of emerged shoots that flowered: 93.1

- Days from Shoot Emergence to Harvest

Shortest time to bloom: 131

Mean time to bloom: 164.5

Longest time to bloom: 249

\section{H. orthotricha 'Eden Pink'}

- Seasonality: Year-round

- Total yield (18 months) for five plants: 329

- Percent of emerged shoots that flowered: 85.9

- Days from Shoot Emergence to Harvest

Shortest time to bloom: 170

Mean time to bloom: 204.7

Longest time to bloom: 249

\section{H. orthotricha 'Garden of Eden'}

- Seasonality: Year-round

- Total yield (18 months) for five plants: 383

- Percent of emerged shoots that flowered: 100

- Days from Shoot Emergence to Harvest

Shortest time to bloom: 125

Mean time to bloom: 162.5

Longest time to bloom: 255

\section{H. caribaea 'Purpurea'}

- Seasonality: Year-round

- Total yield (18 months) for five plants: 54

- Percent of emerged shoots that flowered: 43.2

- Days from Shoot Emergence to Harvest

Shortest time to bloom: 236

Mean during July-Oct: 260.8

Mean during Dec.-Mar. 355.1

Longest time to bloom: 423

\section{'Temptress'}

- Seasonality: Year-round

- Total yield (18 months) for two plants: 30

- Percent of emerged shoots that flowered: 50

- Days from Shoot Emergence to Harvest

Shortest time to bloom: 310

Mean time to bloom: 355

Longest time to bloom: 391
‘Guadaloupe'

- Seasonality: Year-round

- Total yield (18 months) for five plants: 755

- Percent of emerged shoots that flowered: 82.2

- Days from Shoot Emergence to Harvest

Shortest time to bloom: 194

Mean time to bloom: 221.8

Longest time to bloom: 261

\section{'Incredible Orange'}

- Seasonality: June-Oct.

- Total yield (18 months) for five plants: 448

- Percent of emerged shoots that flowered: 72.8

- Days from Shoot Emergence to Harvest

Shortest time to bloom: 205

Mean during July-Oct: 225.5

Mean during Dec.-Mar. 360.4

Longest time to bloom: 411

\section{H. bihai 'Claw \#2'}

- Seasonality: March - May

- Total yield (18 months) for five plants: 213

- Percent of emerged shoots that flowered: 50.8

- Days from Shoot Emergence to Harvest

Shortest time to bloom: 206

Mean time to bloom: 315.2

Longest time to bloom: 370

\section{H. rostrata 'Ten Day Rostrata'}

- Seasonality: Jan.-March, Small summer production

- Total yield (18 months)for five plants: 195

- Percent of emerged shoots that flowered: 66.1

- Days from Shoot Emergence to Harvest

Shortest time to bloom: 208

Mean time to bloom: 242.2

Mean during summer: 307.3

Longest time to bloom: 362

\section{H. stricta 'Red Stricta'}

- Seasonality: Oct.- Feb.

- Total yield (18 months) for five plants: 356

- Percent of emerged shoots that flowered: 85.6

- Days from Shoot Emergence to Harvest

Shortest time to bloom: 168

Mean time to bloom: 218.7

Longest time to bloom: 275

\section{'Keanae'}

- Seasonality: Year-round

- Total yield (18 months) for five plants: 785

- Percent of emerged shoots that flowered: 96.1

- Days from Shoot Emergence to Harvest

Shortest time to bloom: 110

Mean time to bloom: 148.7

Longest time to bloom: 243 


\section{'New Yellow Parrot'}

- Seasonality: Year-round

- Total yield (18 months) for five plants: 705

- Percent of emerged shoots that flowered: 97

- Days from Shoot Emergence to Harvest

Shortest time to bloom: 101

Mean during July-Oct: 119.8

Mean during Dec.-Mar.: 163.8

Longest time to bloom: 215

\section{H. $\times$ rauliniana}

- Seasonality: April-June

- Total yield (18 months) for five plants: 433

- Percent of emerged shoots that flowered: 95.7

- Days from Shoot Emergence to Harvest

Shortest time to bloom 222

Mean during 1st year: 244.7

Mean during 2nd year: 351.3

Longest time to bloom: 382

\section{H. angusta 'Yellow Christmas'}

- Seasonality: Nov.-Dec.

- Total yield (18 months) for two plants: 6

- Percent of emerged shoots that flowered: 5.8

- Days from Shoot Emergence to Harvest

Shortest time to bloom: 231

Mean time to bloom: 270.5

Longest time to bloom: 350

\section{H. dmitri 'Hot Rio Nights'}

- Seasonality: peak: Feb.-May

- Total yield (18 months) for five plants: 287

- Percent of emerged shoots that flowered: 95.7

- Days from Shoot Emergence to Harvest

Shortest time to bloom: 231

Mean during 1st year: 242.2

Mean during 2nd year: 298.5

Longest time to bloom: 367

\section{H. chartacea 'Sexy Pink'}

- Seasonality: Year-round

- Total yield (18 months) for five plants: 61

- Percent of emerged shoots that flowered: 51.7

- Days from Shoot Emergence to Harvest

Shortest time to bloom: 182

Mean time to bloom: 248.5

Longest time to bloom: 358

\section{H. bihai 'Peachy Orange'}

- Seasonality: Feb.-June

- Total yield (18 months) for five plants: 326

- Percent of emerged shoots that flowered: 92.1

- Days from Shoot Emergence to Harvest

Shortest time to bloom: 101

Mean during 1st year: 192.7

Mean during 2nd year: 242.2

Longest time to bloom: 286.8 